\title{
Genetics of Möbius syndrome
}

\author{
M. BARAITSER ${ }^{1,2}$ \\ From MRC Clinical Genetics Unit, Institute of Child Health, and Institute of Neurology, Queen's Square, \\ London
}

SUMMARY A study of the sibs and parents of 15 children diagnosed as having the Möbius syndrome suggests that the inclusion of primary skeletal defects as obligatory in the diagnosis of the syndrome helps to exclude the high risk monogenic disorders of muscle and anterior horn cell, which present with a Möbius-like facies in infancy.

The essential features of the Möbius syndrome have been added to since Möbius first (1888) suggested that the congenital bilateral facial weakness and bilateral abducens palsies constituted a clinical entity.

To the unilateral or bilateral complete or incomplete facial weakness and loss of abduction of the eye have been added other cranial nerve palsies (predominantly bulbar), congenital abnormalities of the extremities (syndactyly, polydactyly, brachydactyly, agenesis of digits, talipes equinous varus), micrognathia, prominent epicanthic folds, structural abnormalities of the ear, and defective branchial musculature $(15 \%$ of cases have missing muscle groups, especially the pectoral or trapezius muscle). Mild mental retardation is thought to occur in about $10 \%$ of cases.

Henderson (1939) reviewed the literature and added one case of his own. The diagnosis was based on facial diplegia, usually accompanied by palsies of other cranial nerves-particularly the ocular. Of the collected cases, 45 out of 61 had abducens involvement. Malformation of the limbs was frequently encountered. Hand deformities were present in 13 out of the 61.

Richards (1953) reviewed the published papers up to that date and more restrictively described the essential features of the Möbius syndrome as: (1) unilateral or bilateral loss of abduction of the eye; (2) unilateral or bilateral complete or incomplete

1This work was done when the author was in receipt of a grant from the Brain Research Trust.

2Present address: The Kennedy-Galton Centre for Clinical Genetics, Harperbury Hospital, Shenley, Radlett, Herts WD7 9HQ.

Received for publication 15 April 1977 facial weakness; (3) primary or secondary congenital abnormalities of the extremities. To the above three criteria, Richards added 'possible other involvement of branchial musculature', by which he refers to the absence of pectoral muscles and the presence of bulbar involvement.

More recently, Van Allen and Blodi (1960) have retained only the first two of Richards' criteria as the essential features of the syndrome, though they mention that primary deformities of the extremities are common.

In view of the difficulties of definition, the role of inheritance in the Möbius syndrome understandably remains uncertain, and it is at present difficult to give genetic advice to parents with an affected child.

In order to try and throw more light on both the definition and the genetics of the condition, all those children diagnosed as having the Möbius syndrome at The Hospital for Sick Children, Great Ormond Street, over the past 18 years were re-examined, as were their parents and all their first degree relatives.

Diagnosis in these children appears to have been based on the facial appearance soon after birth and was made irrespective of the presence or absence of skeletal malformations.

\section{Method}

A search through the records of The Hospital for Sick Children revealed 29 patients in whom the diagnosis had been made (usually by the late Dr Sandifer, who was particularly interested in the syndrome).

Out of a total number of 29 patients, 8 had died soon after birth (4 of these from respiratory or bulbar problems), 6 could not be traced, and of the 15 that 
remained all were visited and examined except one. This child, however, was included because adequate information was available about him.

The probands were examined clinically and in a minority of instances electromyographically. The parents were only examined clinically.

\section{Results}

CLINICAL

A summary of the clinical findings can be seen in the Table. All the patients had bilateral facial weakness and all had difficulty with swallowing. Ocular palsies were less common than the bulbar involvement, but
Both children were mentally normal. Electro- $\stackrel{\mathbb{2}}{\circ}$ myographic studies limited to the limbs on both $\mathcal{Q}$ sibs were compatible with myopathic lesions and there was evidence from the mother that both $\cdot$ children were slowly getting worse.

Case 13, a brother of the proband, had bilateral facial weakness. He slept with his eyes open, had problems with articulation and swallowing (now $\overline{\frac{0}{5}}$ much improved), and could not whistle or blow out ${ }_{\mathbb{\Phi}}$ his cheeks. There seemed to be no obvious progres- $\bigcirc$ sion of the disorder in either brother and they were कs both mentally normal.

Consanguinity was not a feature of either family

Table Clinical findings

\begin{tabular}{|c|c|c|c|c|c|c|}
\hline $\begin{array}{l}\text { Case } \\
\text { No. }\end{array}$ & $\begin{array}{l}\text { Facial } \\
\text { weakness }\end{array}$ & $\begin{array}{l}\text { Abducens } \\
\text { palsy }\end{array}$ & $\begin{array}{l}\text { Palatal } \\
\text { weakness }\end{array}$ & $\begin{array}{l}\text { Skeletal } \\
\text { malformations }\end{array}$ & $\begin{array}{l}\text { Mental } \\
\text { retardation }\end{array}$ & Other CNS signs \\
\hline 1 & Bilateral & Bilateral & Present & - & Mild & - \\
\hline 2 & Bilateral & Bilateral & Present & - & Severe & - \\
\hline 3 & Bilateral & Unilateral & Present & Club feet & Mild & 3rd nerve palsy \\
\hline 4 & Bilateral & Bilateral & Present & Bilateral club feet & Severe & Athetoid movements \\
\hline 5 & Bilateral & - & Present & - & Severe & - \\
\hline 6 & Bilateral & Unilateral & Present & Arthrogryposis & - & Epileptic \\
\hline 7 & Bilateral & Bilateral & Present & Syndactyly & Moderate & - \\
\hline 8 & Bilateral & Bilateral & Present & Club feet & Moderate & - \\
\hline 9 & Unilateral & Bilateral & Present & - & - & - \\
\hline 10 & Bilateral & Unilateral & Present & Club feet & - & - \\
\hline 11 & Bilateral & - & Present & - & Mild & - \\
\hline 12 & Bilateral & - & Present & - & - & - \\
\hline 13 & Bilateral & - & Present & - & - & - \\
\hline 14 & Bilateral & Bilateral & Present & $\begin{array}{l}\text { Syndactyly, } \\
\text { brachydactyly }\end{array}$ & Severe & - \\
\hline
\end{tabular}

when present (in 11 out of the 15 cases) it was bilateral in 8 and involved only the abducens in all 11. Only 2 of the 15 patients had primary skeletal malformations (one having syndactyly, and the other brachydactyly and syndactyly), and can, therefore, be included in Richards' definition of the Möbius syndrome, whereas 11 fulfil the criteria of Van Allen and Blodi (facial and ocular weakness), and all 15 fulfil the criteria of Henderson (only facial weakness).

Of the 15 patients diagnosed clinically as having the syndrome, there were 2 instances where more than one member of the family was found to be affected.

The male proband (case 10, Table) had a right abducens paralysis, had swallowing difficulty at birth, and was dysarthric. His palate moved sluggishly. Movements of his tongue were poor and there was a suggestion of atrophy on the right side. His sister had bilateral facial weakness, but no eye muscle involvement. She had atrophy in the proximal musculature of arms and legs, and there was also some distal wasting in the small muscles of the hand. Tongue and palate moved normally and there was no dysphagia. and the parents of both families were examined and found to be clinically normal.

Clinical examination of the parents of the other probands revealed no abnormalities. Special attention was paid to features of dystrophia myotonica but these were not present.

In this study, bulbar involvement was a prominent feature (not included as obligatory in either the definition of Henderson, Allen and Blodi, or Richards) and mental retardation of a severe kind occurred in just over half of the index cases.

\section{Discussion}

Hanson and Rowland (1971) emphasise the difficulty $\frac{7}{2}$. in making a diagnosis of the Möbius syndrome soon $N$ after birth. One of their so-called Möbius syndromes progressed to a typical facio/scapulo/humeral mus- $\tilde{N}$ cular dystrophy. Vanier (1960) and Harper and $\underset{\omega}{N}$ Dyken (1972) described cases of infantile myotonic dystrophy that were remarkably like the Möbius 0 syndrome. However, bilateral abducens paralysis is not a common feature of infantile myotonic dys- ? 
trophy and the infants' mothers are almost invariably affected in this dominantly inherited disorder.

Of the patients quoted in the literature as having the Möbius syndrome affecting more than one member of the family (Fortanier and Speijer, 1935; van der Wiel, 1957; Krueger and Friedrich, 1963), three of the pedigrees are clearly dominant, with at least three generations affected, but the group is probably heterogeneous; van der Wiel, for example, uses the term monosymptomatic Möbius syndrome synonymously with facial diplegia. No members of the three pedigrees had skeletal malformations. Thomas (1898) and Cadwalader (1922) described affected sibs and, in Cadwalader's family, the affected brother and sister were the product of a consanguineous marriage, suggesting recessive inheritance. In both of these families, deafness occurred and there were no skeletal deformities. The only reported family with primary skeletal disorder and the Möbius facies in more than one member is that of Hicks (1943). Mother and son had bilateral facial weakness and abducens palsies, but the son had, in addition, an extra thumb and webbing of his fingers.

If, in addition to the facial diplegia and abducens palsies, Richards' criteria of primary skeletal malformations are included as an essential feature of the syndrome, then the Möbius syndrome becomes much less heterogeneous. In the present series, the two index patients, with another sib affected, do not fulfil the criteria of Richards and the two patients with primary skeletal malformations, facial diplegia, and bilateral abducens have no other family members who are similarly affected.

Based on the present series and more than 50 cases reported in the literature, it is concluded that when the definition of the Möbius syndrome includes the skeletal malformations, the risk to offspring is in the region of $2 \%$, whereas, in facial diplegia with or without eye muscle involvement, the hereditary predisposition is greater and will depend on the condition being categorised as belonging to one of the known genetically determined primary muscle or anterior horn cell disorders.

\section{References}

Cadwalader, W. B. (1922). A clinical report of two cases of agenesis (congenital paralysis) of the cranial nerve. American Journal of the Medical Sciences, 163, 744-748.
Fortanier, A. H., and Speijer, N. (1935). Eine Erblichkeitsforschung bei einer Familie mit angeborenen Beweglichkeitsstoreungen der Hirnnerven (infantiler Kernschwund von Moebius). Genetica, 17, 471-486.

Hanson, P. A., and Rowland, L. P. (1971). Möbius syndrome and fascioscapulo-humeral muscular dystrophy. Archives of Neurology, 24, 31-39.

Harper, P. S., and Dyken, P. R. (1972). Early-onset dystrophia myotonica. Lancet, 2, 53-54.

Henderson, J. L. (1939). The congenital facial diplegia syndrome. Clinical features, pathology and aetiology. A review of sixty-one cases. Brain, 62, 381-403.

Hicks, A. M. (1943). Congenital paralysis of lateral rotators of eyes with paralysis of muscles of face. Archives of Ophthalmology, 30, 38-42.

Krueger, K. E., and Friedrich, D. (1963). Familiaere kongenitale Motilitaetsstoerungen der Augen. Klinische Monatsblätter für Augenheilkunde, 142, 101-117.

Möbius, P. J. (1888). Über angeborenen doppelseitige Abducens-Facialis-Lähmung. Münchener medizinische Wochenschrift, 35,91-94.

Richards, R. N. (1953). The Möbius syndrome. Journal of Bone and Joint Surgery. A. American Volume, 35, 437-444.

Thomas, H. M. (1898). Congenital facial paralysis. Journal of Nervous and Mental Disease, 25, 571-593.

Van Allen, M. W., and Blodi, F. C. (1960). Neurologic aspects of the Möbius syndrome. Neurology, 10, 249-259.

van der Wiel, H. J. (1957). Hereditary congenital facial paralysis. Acta Genetica et Statistica Medica, 7, 348.

Vanier, T. M. (1960). Dystrophia myotonica in childhood. British Medical Journal, 2, 1284-1288.

Requests for reprints to Dr M. Baraitser, The Kennedy-Galton Centre for Clinical Genetics, Harperbury Hospital, Harper Lane, Shenley, Radlett, Herts WD79HQ.

\section{Appendix}

\begin{tabular}{llrr}
\hline \multirow{2}{*}{$\begin{array}{l}\text { Serial } \\
\text { No. }\end{array}$} & Sibs & \multicolumn{2}{c}{ Date of birth } \\
\cline { 3 - 4 } & & Father & Mother \\
\hline & & $10 / 37$ & $2 / 40$ \\
1 & M 6/70, F 1/72* & $6 / 47$ & $8 / 48$ \\
2 & F 2/71*, M 3/73 & $9 / 28$ & $12 / 28$ \\
3 & M 12/57*, M 6/61 & $12 / 32$ & $6 / 34$ \\
4 & M 6/57, F 4/65*, F 4/65 & $6 / 10$ & $2 / 28$ \\
5 & F 8/53, F 2/56, F 3/58* & $1 / 33$ & $7 / 34$ \\
6 & F 6/54* & $1 / 27$ & $6 / 29$ \\
7 & M 6/54, F 3/60* & $6 / 39$ & $2 / 40$ \\
8 & F 1/60*, F 4/61, F 3/63 & $3 / 44$ & $1 / 44$ \\
9 & F 3/71*, F 3/74 & $6 / 33$ & $1 / 34$ \\
10 & F 3/54, F 2/57, M 9/58*, F 8/64 (A) & $6 / 30$ & $3 / 25$ \\
11 & M 9/55*, M 2/57 & $2 / 36$ & $8 / 34$ \\
12 & M 1/56* & $10 / 32$ & $6 / 35$ \\
13 & M 6/56*, F 2/60, M 4/67 (A), M 3/72 $5 / 35$ & $6 / 34$ \\
14 & M 9/59*, M 2/63 & $9 / 39$ & $3 / 41$ \\
15 & M 3/62, M 8/65*, M 7/67 & & \\
\hline
\end{tabular}

M, male; F, female; *, index patient; (A), affected. 